\title{
Reality and challenges of ageing
}

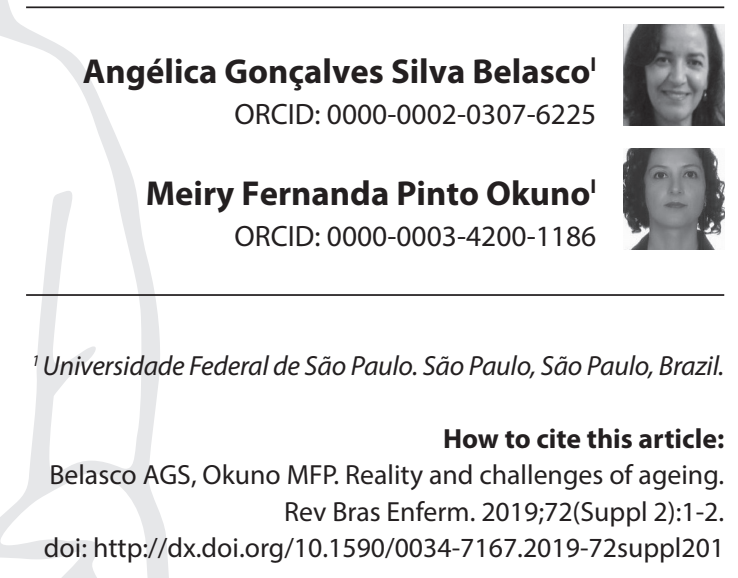

doi: http://dx.doi.org/10.1590/0034-7167.2019-72suppl201
The global population ageing has aroused growing interest, a search for an understanding of the situational consequences and possible adjustments that society will have to make. According to the Brazilian Institute of Geography and Statistics (IBGE - Instituto Brasileiro de Geografia e Estatística), in 2025 , the country will place the $6^{\text {th }}$ position in the world in regards to amount of elderly. It is estimated that by 2055 , the number of people over 60 years will surpass that of Brazilians under the age of 30. In 2018, the ageing rate was 43.19 percent, and could reach 173.47 percent by $2060^{(1-2)}$.

Ageing, for many, marks the period of diminished functional capacity, perform Instrumental Activities of Daily Living (IADL), which are tasks such as shopping, administering finances, taking medicines, using means of transportation, using the telephone, and doing chores can gradually be compromised and even generate complete dependence. Brazilian records in 2018 indicated that 39.2 percent of the elderly over 75 years of age present a decline in the capacity to perform the IADL, which may be a reflection of the high prevalence rate of chronic diseases among the elderly. 69.5 percent had a diagnosis of at least one chronic illness, and 77 percent of Brazilians reported that the greatest fears related to old age were health problems, financial concern, and degradation of physical appearance, level of responsibility and energy ${ }^{(2)}$.

The Global Age Watch quality of life report in 2017 considered factors such as life expectancy, psychological well-being, income, transportation, and security; and Brazil ranked $56^{\text {th }}$ out of 96 countries. In terms of income security, the country appeared in 13th place, and retirement emerged as the main reason, since about 87 percent of the population over 60 had fixed income and the extreme poverty rate among the elderly was below 10 percent ${ }^{(3)}$.

Based on the reality described above, most people will live beyond the age of 60, and the consequences for the Brazilian Unified Health System (Sistema Único de Saúde), which currently serves only about 76 percent of the country's elderly, will need to adapt to the new reality of ageing in the country. population, as well as health workers. Changes in health policies and in the way services are delivered will need to overcome stereotyped and outdated models of older people.

According to the World Health Organization (WHO)'s World Report on Ageing and Health (WRAH), there is no pattern of the elderly. Diversities in the capacities and health needs of each other, arising from the course of life, make them unique and modifiable often. Although there are a number of health problems, as age progresses, this does not necessarily imply a mandatory decline in capacity or a substantial increase in health care costs for the elderly. In the United States, between 1940 and 1990, ageing accounted for about 2 percent of health spending, while technology-related changes accounted for spending between 38 and 65 percent ${ }^{(4)}$. And what, in fact, should be the goal of immense investments in technology, if not the improvement of the quality of life of people, regardless of age?

Changes in paradigms may help in the new social-political-economiccultural and health structure in Brazil. Tackling the economic imbalance of ageing has been a form of violence committed against older people. 
Ageing is inherent in human beings, we age every day, so the appreciation of people should not be tied to their age. Ageing is a precious opportunity that needs to occur in a healthy way, but unfortunately many do not grow old with quality and dignity. For the majority of the elderly, healthy ageing allows the maintenance of the functional capacity, besides the absence or control of diseases. Overall, families and society are concerned about the costs of maintaining the elderly's health. They do not realize that investments in promoting the functional capacity of the elderly can bring up immense benefits to all, quality of life for the elderly, less wear and tear for the family, and economy for the health system in medium term. Innovative solutions are constantly being developed in the most diverse fields of knowledge, many of them with low costs and exorbitant results. Such initiatives need to be encouraged to seek improvement in the scenario of the elderly in Brazil and in the world.

The construction of a more favorable world for the elderly requires changes in the health system, in order to substitute curative models for models of comprehensive care centered on the elderly's needs, allowing them and society the maximum use of this phase of life. A longer life can provide opportunities for personal growth, pursuit of fulfillment, achievement, well-being, exclusion from prejudices, and often inflexible rules experienced throughout life.

For many years, the challenges to government, health professionals, and society in relation to the search for strategies that can benefit the most advanced human beings have been launched, but despite some successful initiatives, there is still much to be done. Here is the invitation to invest in a better world for all!

\section{REFERENCES}

1. Andrade H. IBGE projeta Brasil com mais idosos do que crianças em 21 anos [Internet]. 25 de julho de 2018 [cited 2019 Jun 19$]$. Portal UOL. Available from: https://noticias.uol.com.br/cotidiano/ultimas-noticias/2018/07/25/ibge-projeta-brasil-com-mais-idosos-do-que-criancasem-21-anos.htm

2. Perissé C, Marli M. Idosos indicam caminhos para uma melhor idade. Rev Retratos [Internet]. 19 de março de 2019 [cited 2019 Jun 19]. Available from: https://agenciadenoticias.ibge.gov.br/agencia-noticias/2012-agencia-de-noticias/ noticias/24036-idosos-indicam-caminhos-para-uma-melhor-idade

3. Brasil é o $56^{\circ}$ melhor país do mundo para envelhecer. Rev Exame [Internet]. 9 de setembro de 2015[cited 2019 Jun 19]. Available from: https://exame.abril.com.br/brasil/brasil-e-o-56o-em-ranking-de-melhor-pais-para-idosos

4. Organização Mundial da Saúde. Relatório mundial de envelhecimento e saúde [Internet]. 2015[cited 2019 Jun 19]. Available from: https:// sbgg.org.br//wp-content/uploads/2015/10/OMS-ENVELHECIMENTO-2015-port.pdf 